\section{Different Extracts of Zingiber officinale Decrease Enterococcus faecalis Infection in Galleria mellonella}

Lilian Eiko Maekawa², Rodnei Dennis Rossoni', Júnia Oliveira Barbosa', Antonio Olavo Cardoso Jorge ${ }^{1}$, Juliana Campos Junqueira ${ }^{1}$, Marcia Carneiro Valera $^{2}$

Dried, fresh and glycolic extracts of Zingiber officinale were obtained to evaluate the action against $G$. mellonella survival assay against Enterococcus faecalis infection. Eighty larvae were divided into: 1) E. faecalis suspension (control); 2) E. faecalis + fresh extract of Z. officinale (FEO); 3) E. faecalis + dried extract of Z. officinale (DEO); 4) E. faecalis + glycolic extract of $Z$. officinale (GE0); 5) Phosphate buffered saline (PBS). For control group, a $5 \mu \mathrm{L}$ inoculum of standardized suspension $\left(10^{7}\right.$ cells $/ \mathrm{mL}$ ) of $E$. faecalis (ATCC 29212) was injected into the last left proleg of each larva. For the treatment groups, after $E$. faecalis inoculation, the extracts were also injected, but into the last right proleg. The larvae were stored at $37^{\circ} \mathrm{C}$ and the number of dead larvae was recorded daily for 168 $\mathrm{h}$ (7 days) to analyze the survival curve. The larvae were considered dead when they did not show any movement after touching. E. faecalis infection led to the death of $85 \%$ of the larvae after $168 \mathrm{~h}$. Notwithstanding, in treatment groups with association of extracts, there was an increase in the survival rates of 50\% (GEO), 61\% (FEO) and 66\% (DEO) of the larvae. In all treatment groups, the larvae exhibited a survival increase with statistically significant difference in relation to control group $(p=0.0029)$. There were no statistically significant differences among treatment groups with different extracts $(p=0.3859)$. It may be concluded that the tested extracts showed antimicrobial activity against $E$. faecalis infection by increasing the survival of Galleria mellonella larvae.

\author{
'Department of Biosciences \\ and Oral Diagnosis, Institute of \\ Science and Technology, UNESP \\ - Univ Estadual Paulista, São \\ José dos Campos, SP, Brazil \\ ${ }^{2}$ Department of Restorative Dentistry, \\ Institute of Science and Technology, \\ UNESP - Univ Estadual Paulista, \\ São José dos Campos, SP, Brazil
}

Correspondence: Rodnei Dennis Rossoni, Avenida Engenheiro Francisco José Longo, 777, 12245000 São José dos Campos, SP, Brasil. Tel: +55-12-3947-9033. e-mail: dennisrossoni@hotmail.com

Key Words: Enterococcus faecalis, Zingiber officinale, host-pathogen interactions, Galleria mellonella.

\section{Introduction}

One of the endodontic treatment goals is to eliminate the infection within root canals and prevent postendodontic treatment reinfection. However, Bystrom and Sundqvist (1) showed that microorganisms can survive even after biomechanical preparation and Enterococcus faecalis (Gram-positive, facultative anaerobic coccus) has been frequently isolated in root canals exhibiting persistent post-endodontic treatment infections $(2,3)$.

In cases of pulp necrosis with radiographic sign of apical periodontitis and lack of periodontal disease, E. faecalis was isolated in 55\% (4) and 64\% of the cases (2). Microbiological identification and analytic studies of teeth presenting endodontic treatment and periapical lesion verified that this microorganism is the most prevalent species, present in $45 \%$ (3), $77 \%$ (5) and up to $77.8 \%$ (6) of the cases.

Different substances have been used to reduce microorganism counts within root canal system, such as sodium hypochlorite, chlorhexidine, citric acid, saline and alternative therapies using natural medicinal plants that seem to be most promising solutions $(7,8)$.

Zingiber officinale is a plant native to India and China, which has been largely employed as flavoring, in alcoholic beverages and in popular medicine. It has been extensively used in traditional Chinese medicine to treat headaches, nausea, fever, arthritis, rheumatisms and muscle pains. The active constituents of ginger comprise gingerols and shogaols, and the first is the main biological active constituent accounting for the anti-inflammatory and analgesic properties of ginger (9). Analyzing the active constituents of ginger, Lantz et al. (10) verified that both gingerol and shogaol were capable of significantly inhibit the production of prostaglandins $E_{2}$ induced by LPS from Escherichia coli. The extracts containing mainly gingerol had the capacity of inhibiting COX-2 production, while those containing shogaol did not show effect on COX-2.

Previous studies in vitro showed the antimicrobial action of Z. officinale, as Kim and Park (11), who evaluated the glycolic extract of $Z$. officinale on Pseudomonas aeruginosa biofilm. The authors demonstrated that biofilm development was reduced in up to $56 \%$ when the phytotherapic drug was added to the bacterial culture. Maekawa et al. (7) also observed antimicrobial action of Z. officinale and verified that 20\% glycolic extract of ginger (Apis Flora) as intracanal medication for 14 days was effective in eliminating Candida albicans, E. faecalis and E. coli.

Currently, invertebrate animal models, such as the 
nematode Caenorhabditis elegans, and insets, such as Drosophila melanogaster and Galleria mellonella, have been used in the study of the microorganism pathogenicity, host-pathogen interaction and as screening for testing new therapies (12). Invertebrates have several advantages over the conventional mammalian models, including lower costs, faster results and fewer ethical issues (13).

G. mellonella is a reliable and proven experimental model for pathogenesis studies and innate immunity, because it has in its hemolymph six types of hemocytes (prohemocytes, coagulocytes, spherulocytes, oenocytoids, plasmocytes and granulocytes), which play an important role in host-pathogen interaction $(14,15)$.

Since studies in vivo are crucial for the study of the pathogenesis of micro-organisms and development of alternative treatments, the aim of this study was to evaluate and compare in vivo the effectiveness of dried, fresh and glycolic extract of Zingiber officinale essential oils against experimental infection by E. faecalis in G. mellonella model.

\section{Material and Methods}

\section{Microorganism and Culture}

A standard Enterococcus faecalis strain (ATCC 29212) was used. This strain came from the Laboratory of Microbiology and Immunology of the Institute of Science and Technology/UNESP. To perform the G. mellonella trials, the microorganism was seeded in Petri plates containing brain heart infusion agar (BHI) (Difco, Detroit, MI, USA) and incubated at $37{ }^{\circ} \mathrm{C}$ for $24 \mathrm{~h}$. After this, E. faecalis colonies were suspended in sterilized saline solution $(0.9 \% \mathrm{NaCl})$ to obtain a standardized suspension of $10^{7}$ cells $/ \mathrm{mL}$ by spectrophotometry (B 582, Micronal, São Paulo, SP, Brazil).

Table 1. Experimental groups

\begin{tabular}{|c|c|c|}
\hline Group & $n$ & Description \\
\hline $\begin{array}{l}\text { E. faecalis + FEO } \\
(2.5 \mathrm{mg} / \mathrm{mL})\end{array}$ & 16 & $\begin{array}{r}5 \mu \mathrm{L} \text { E. faecalis - left proleg } \\
5 \mu \mathrm{L} \text { FEO - right proleg }\end{array}$ \\
\hline $\begin{array}{l}\text { E. faecalis + DEO } \\
(5 \mathrm{mg} / \mathrm{mL})\end{array}$ & 16 & $\begin{array}{l}5 \mu \mathrm{L} \text { E. faecalis - left proleg } \\
5 \mu \mathrm{L} \text { DEO - right proleg }\end{array}$ \\
\hline $\begin{array}{l}\text { E. faecalis + GEO } \\
(2.5 \mathrm{mg} / \mathrm{mL})\end{array}$ & 16 & $\begin{array}{l}5 \mu \mathrm{L} \text { E. faecalis - left proleg } \\
5 \mu \mathrm{L} \mathrm{GEO} \mathrm{-} \mathrm{right} \mathrm{proleg}\end{array}$ \\
\hline E. faecalis (Control) & 16 & $\begin{array}{l}5 \mu \mathrm{L} \text { E. faecalis - left proleg } \\
5 \mu \mathrm{L} \text { PBS - right proleg }\end{array}$ \\
\hline PBS & 16 & $\begin{array}{l}5 \mu \mathrm{L} \text { PBS - left proleg } \\
5 \mu \mathrm{L} \text { PBS - right proleg }\end{array}$ \\
\hline
\end{tabular}

FEO: fresh extract; DEO: dried extract; GEO: glycolic extract; PBS: phosphate buffered saline

\section{Used Phytotherapics}

The plant used in this study was Zingiber officinale Roscoe. The dried and fresh extracts of $Z$. officinale were purchased at the Collection of Medicinal and Aromatic Plants of the Multidisciplinary Clinical, Biological and Agricultural Research Center of UNICAMP (MCBARS). The MCBARS has the botanical identification of the studied plant, as well as its own store in a herbarium voucher specimen of the University, with registration number 533 corresponding to Zingiber officinale Roscoe. The glycolic extracts of Z. officinale were purchased from Apis Flora ${ }^{\circledast}$, Ribeirão Preto, SP, Brazil. The obtained products were used at a $2.5 \mathrm{mg} / \mathrm{mL}$ concentration for fresh and glycolic extracts and $5.0 \mathrm{mg} / \mathrm{mL}$ for dried extract.

In Vivo Evaluation of the Combination of E. faecalis Strain with Galleria mellonella Experimental Model

This study employed the methodology described by Mylonakis (14) and Cowen et al. (15) with some modifications. Sixteen randomly chosen G. mellonella larvae at final larval stage with body weight of approximately $330 \pm 25 \mathrm{mg}$ were used for each group, totalizing 80 animals. The following groups were established: 1) E. faecalis suspension (control); 2) E. faecalis + fresh extract of $Z$. officinale (FEO); 3) E. faecalis + dried extract of Z. officinale (DEO); 4) E. faecalis + glycolic extract of Z. officinale (GEO); 5) Phosphate buffered saline (PBS). In the control group, a $5 \mu \mathrm{L}$ inoculum of standardized suspension $\left(10^{7} \mathrm{cell} / \mathrm{s} / \mathrm{mL}\right)$ of E. faecalis (ATCC 29212) was injected into the last left proleg of each larva. For treatment groups, after E. faecalis inoculation, the extracts were also injected, but into the last right proleg (Table 1). Two control groups were included in the assays as part of this study: one group was inoculated with PBS to enable observation of the demise of the larvae due to physical trauma, and the other received no injection as a control for general viability.

Following inoculation, the larvae were stored in plastic containers at $37^{\circ} \mathrm{C}$ and the number of killed G. mellonella was recorded daily for $168 \mathrm{~h}$ ( 7 days) to analyze the survival curve. The larvae were considered dead when they did not show any movement after touching. During all assays performed in this study, the larvae did not receive nutrition.

\section{Statistical Analysis}

Percent survival and killing curves of G. mellonella were plotted and statistical analysis was performed by the Logrank (Mantel-Cox) test using Graph Pad Prism statistical software. Significance level was set at $p<0.05$.

\section{Results}

The treatment with different extracts of $Z$. officinale was effective in reducing in vivo infection in G. mellonella. 
Z. officinale at a $2.5 \mathrm{mg} / \mathrm{mL}$ concentration of fresh and glycolic extracts, and $5.0 \mathrm{mg} / \mathrm{mL}$ of dried extract showed antimicrobial action against $E$. faecalis by protective action against experimental infection in G. mellonella.

The infection by $E$. faecalis without any treatment (control group) led to the death of $85 \%$ of the larvae after $168 \mathrm{~h}$. However, in the groups treated with essential oils, was verified a $50 \%$ increase in the larva survival rates for glycolic extract (Fig. 1A), 61\% for fresh extract (Fig. 1B) and $66 \%$ for dried extract (Fig. 1C).

In all groups treated with essential oils, the larvae exhibited a survival increase with statistically significant difference in relation to control group, for glycolic extract $(p=0.0444)$, fresh extract $(p=0.0013)$ and dry extract $(p=0.0022)$. There was no statistically significant difference among different extracts of $Z$. officinale showing similarity and effectiveness of different treatments $(p=0.3859)$ (Fig. 2). This suggests that the different tested extracts showed antimicrobial activity against $E$. faecalis infection increasing
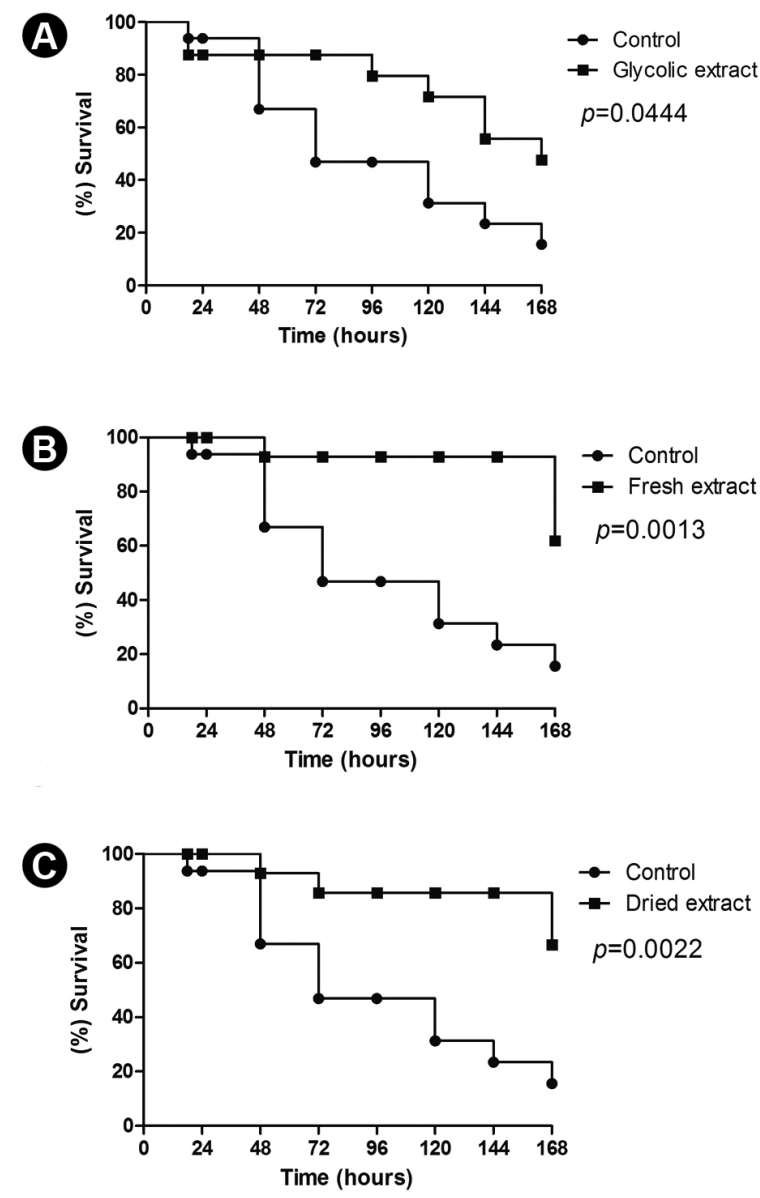

Figure 1. Survival curve of G. mellonella infected with E. faecalis. A: E. faecalis infection and treatment with glycolic extract. B: Infection with $E$. faecalis and treatment with fresh extract. C: Infection with $E$. faecalis and treatment with dried extract. the survival of larvae of G. mellonella when compared with control group.

\section{Discussion}

The treatment with different extracts of $Z$. officinale was effective in reducing in vivo infection in G. mellonella and probably the biologically active compounds of the extracts were responsible for this reduction. The composition of ginger extracts is very variable, with predominance of biologically active components as gingerols, shogaol, paradols and gingerone. Gingerol and shogaol ratio within the extracts seems to be responsible by the main pharmacologic activities of $Z$. officinale, but dependent on factors as rhizome origin, maturity and preparation methods (9). Moreover, gingerone also present in oils and rhizomes, and is capable of reducing biofilm formation and consequently the in vivo infection (16).

Z. officinale at a concentration of $2.5 \mathrm{mg} / \mathrm{mL}$ of fresh and glycolic extracts and $5.0 \mathrm{mg} / \mathrm{mL}$ of dried extract showed antimicrobial action against $E$. faecalis by protective action against experimental infection in G. mellonella. The exact antimicrobial mechanism by which Z. officinale acts on microorganisms still needs to be clarified (17). However, it may be anticipated that different action mechanisms of this phytotherapic that lead to microbial reduction may be partly due to its hydrophobicity. As a result, there is disruption of the cell membrane lipid bilayer, making it more permeable, causing leakage of the vital cells content (18).

For this study, the GEO group showed increase of 50\% of larva survival, while FEO and DEO groups presented $61 \%$ and $66 \%$ of survival in relation to control group, respectively. This difference found between the groups probably occurred because although GEO had a watersoluble vehicle, it came from a not fresh commercial product, different from the other rhizomes. Both fresh and dried rhizomes were obtained without manufacturing, which may assure purity of the extract and preservation of the product components. To the best of our knowledge,

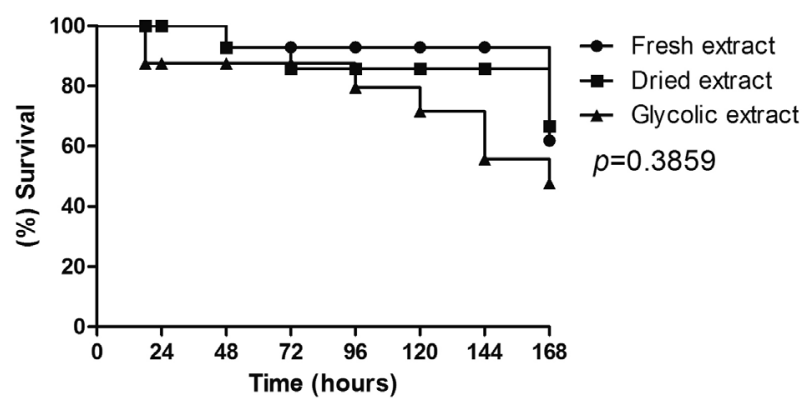

Figure 2. Comparison of the survival curve of G. mellonella larvae infected by $E$. faecalis and treated with different extracts. 
this is the first study on extracts of plants to treat microbial infections in G. mellonella model, consequently there are no studies with similar methodology in order to compare and better discuss the present findings. Even so, these results agree with most published reports regarding the in vitro antimicrobial activity of ginger $(19,20)$.

The increased larvae survival in the treated groups suggests that the active compounds of different extracts associated to the immune system of the larvae were able to control the infection for a longer time compared to the control group. With these results, it may be confirmed that G. mellonella is a suitable model for the study of alternative therapies to fight microbial infection. In agreement with this, Apolónio et al. (21) evaluated the adaptation response of Staphylococcus aureus and Listeria monocytogenes to the essential oil of eugenol in G. mellonella. The adaptation to eugenol was done by sequential exposure of the pathogens to increasing concentrations of this essential oil. After this, they evaluated the impact of adaptation to eugenol on virulence of these bacteria using G. mellonella larvae. As control group, the authors injected these bacteria into the larvae without previous treatment with eugenol. The sequential exposure of $S$. aureus and L. monocytogenes to different concentrations of eugenol affected their virulence, increasing the survival of larvae in comparison with the control group and evidencing the great potential of eugenol to fight these human pathogens.

G. mellonella model was used in this study to evaluate the antimicrobial action of $Z$. officinale on $E$. faecalis infection. The $G$. mellonella experimental model is recent but it is increasingly gaining acceptance in the scientific community. It has presented some advantages as host model, for example: the larvae can be stored at a temperature range from $25^{\circ} \mathrm{C}$ to $37^{\circ} \mathrm{C}$, thus making easier the temperature conditions under which the pathogenic microorganisms exist, both in an environmental niche and in mammals (13). Recently, Mesa-Arango et al. (22) evaluated antifungal effectiveness in this infection model and verified that amphotericin B, caspofungin, voriconazole and fluconazole had a protective effect on animals at concentrations similar to those applied in humans, concluding that $G$. mellonella provided a simple and viable model to study drug effectiveness.

This study verified that $E$. faecalis infection in $G$. mellonella was lethal to $85 \%$ of animals after $168 \mathrm{~h}$ of inoculation. Additionally to Dentistry interest, currently $E$. faecalis has become an important hospital pathogen and most of nosocomial infections have been caused by two species of the genus: E. faecalis and Enterococcus faecium (23). Because of the great importance of these bacteria nowadays, some studies have evaluated the infection with Enterococcus spp. in G. mellonella and found a positive correlation between virulence and host response $(24,25)$.

The results found by the present study corroborate those from in vitro studies found in the literature while simultaneously indicating the need of further studies employing invertebrate models and different trials (phagocytosis, counting of microbial load in hemolymph, tissue cultures, hemocyte count and melanization assays) that may allow analyzing both host and microorganism genes and helping to elucidate the unique characteristics of Enterococcus virulence, like its capacity of inducing a persistent infection.

Within the limits of this study, it may be concluded that the tested essential oils exhibited antimicrobial activity against $E$. faecalis infection by increasing the survival of G. mellonella larvae.

\section{Resumo}

Extratos seco, fresco e glicólico de Zingiber officinale foram obtidos para avaliar suas ações por meio de ensaio de sobrevivência em G. mellonella contra infecção por Enterococcus faecalis. Oitenta larvas foram divididas em: 1) Suspensão de E. faecalis (controle); 2) E. faecalis + extrato fresco de Z. officinale (FEO); 3) E. faecalis + extrato seco de Z. officinale (DEO); 4) E. faecalis + extrato glicólico de Z. officinale (GEO); 5) Solução tampão fosfato salina (PBS). Para o grupo de controle, $5 \mu \mathrm{L}$ de inóculo de suspensão padronizada ( $10^{7}$ células $/ \mathrm{mL}$ ) de $E$. faecalis (ATCC 29212) foi injetado na última proleg esquerda de cada lagarta. Para os grupos com tratamento, após a injeção de $E$. faecalis, os extratos foram injetados na última proleg direita. Após as injeções, as lagartas foram armazenadas a $37^{\circ} \mathrm{C}$ e o número de animais mortos foi registrado diariamente em $168 \mathrm{~h}$ (7 dias) para analisar a curva de sobrevivência. As lagartas foram consideradas mortas quando elas não mostraram qualquer movimento após o toque. A infecção por E. faecalis levou à morte de $85 \%$ das lagartas após 168 h. Não obstante, nos grupos de tratamento com associação dos extratos, houve um aumento nas taxas de sobrevivência de 50\% (GEO), $61 \%$ (FEO) e 66\% (DEO) das lagartas. Em todos os grupos com tratamento, as lagartas apresentaram um aumento na sobrevivência, com diferença estatisticamente significativa em relação ao grupo controle $(p=0,0029)$. Não houve diferença estatisticamente significativa entre os tratamentos com os diferentes extratos $(p=0,3859)$. Pode concluir-se que os extratos testados mostraram atividade antimicrobiana contra a infecção por $E$. faecalis, aumentando a sobrevivência das lagartas de G. mellonella.

\section{Acknowledgements}

The authors are grateful to The São Paulo Research Foundation (FAPESP) for the financial grant (Process no. \#2011/50855-7).

\section{References}

1. Bystrom A, Sundqvist G. The antibacterial action of sodium hypochlorite and EDTA in 60 cases of endodontic therapy. Int Endod J 1985;18:35-40.

2. Peciuliene $V$, Reynaus $A H$, Balciuniene I, Haapasalo M. Isolation of yeast and enteric bacteria in root-filled teeth with chronic apical periodontitis. Int Endod J 2001;34:429-434.

3. Pinheiro ET, Gomes BP, Ferraz CC, Teixeira FB, Zaia AA, Souza Filho FJ. Evaluation of root canal microorganisms isolated from teeth with endodontic failure and their antimicrobial susceptibility. Oral Microbiol Immunol 2003;18:100-103.

4. Vianna ME, Horz HP, Conrads G, Feres M, Gomes BPFA. Comparative analysis of endodontic pathogens using checkerboard hybridization in relation to culture. Oral Microbiol Immunol 2008;23:282-290. 
5. Siqueira JF, Rôças IN. Polymerase chain reaction-based analysis of microorganisms associated with failed endodontic treatment. Oral Surg Oral Med Oral Pathol Oral Radiol Endod 2004;97:85-94.

6. Gomes BP, Pinheiro ET, Jacinto RC, Zaia AA, Ferraz CCR, de Souza-Filho FJ. Microbial analysis of canals of root-filled teeth with periapical lesions using polymerase chain reaction. J Endod 2008;34:537-540.

7. Maekawa LE, Valera MC, Oliveira LD, Carvalho $C A$, Camargo $\mathrm{CH}_{\text {, Jorge }}$ AO. Effect of Zingiber officinale and propolis on microorganisms and endotoxins in root canals. J Appl Oral Sci 2013;21:25-31.

8. Valera MC, Maekawa LE, Chung A, Cardoso FG, Oliveira LD, Oliveira $\mathrm{CL}$, et al.. The effect of sodium hypochlorite and ginger extract on microorganisms and endotoxins in endodontic treatment of infected root canals. Gen Dent 2014;62:25-29.

9. Ali BH, Blunden G, Tanira MO, Nemmar A. Some phytochemical, pharmacological and toxicological properties of ginger (Zingiber officinale Roscoe): a review of recent research. Food Chem Toxicol 2008;46:409-420.

10. Lantz RC, Chen GJ, Sarihan M, Sólyom AM, Jolad SD, Timmermann BN. The effect of extracts from ginger rhizome on inflammatory mediator production. Phytomedicine 2007;14:123-128.

11. Kim HS, Park HD. Ginger extract inhibits biofilm formation by Pseudomonas aeruginosa PA14. PLoS One 2013;8:e76106.

12. Park SY, Kim KM, Lee JH, Seo SJ, Lee IH. Extracellular gelatinase of Enterococcus faecalis destroys a defense system in insect hemolymph and human serum. Infect Immun 2007;75:1861-1869.

13. Junqueira JC. Galleria mellonella as a model host for human pathogens: recent studies and new perspectives. Virulence 2012;3:474-476.

14. Mylonakis E. Galleria mellonella and the study of fungal pathogenesis: making the case for another genetically tractable model host. Mycopathologia 2008;165:1-3.

15. Cowen LE, Singh SD, Köhler JR, Collins C, Zaas AK, Schell WA, et al.. Harnessing $\mathrm{Hsp} 90$ function as a powerful, broadly effective therapeutic strategy for fungal infectious disease. Proc Natl Acad Sci USA 2009;106:2818-2823.

16. Kumar L, Chhibber S, Harjai K. Zingerone inhibit biofilm formation and improve antibiofilm efficacy of ciprofloxacin against Pseudomonas aeruginosa PA01. Fitoterapia 2013;90:73-78.

17. Nostro A, Cellini L, Di Bartolomeo S, Cannatelli MA, Di Campli E, Procopio $F$, et al.. Effects of combining extracts (from propolis or Zingiber officinale) with clarithromycin on Helicobacter pylori. Phytother Res 2006;20:187-190.

18. Burt S. Essential oil: their antibacterial properties and potential applications in foods - a review. Int J Food Microbiol 2004;94:223-253.

19. Gull I, Saeed M, Shaukat H, Aslam SM, Samra ZQ, Athar AM. Inhibitory effect of Allium sativum and Zingiber officinale extracts on clinically important drug resistant pathogenic bacteria. Ann Clin Microbio Antimicrob 2012;11:18.

20. Sebiomo A, Awofodu AD, Awosanya AO, Awotona FE, Ajayi AJ: Comparative studies of antibacterial effect of some antibiotics and ginger (Zingiber officinale) on two pathogenic bacteria. J Microbiol Antimicro 2011;3:18-22.

21. Apolónio J, Faleiro ML, Miguel MG, Neto L. No induction of antimicrobial resistance in Staphylococcus aureus and Listeria monocytogenes during continuous exposure to eugenol and citral. FEMS Microbiol Lett 2014;354:92-101.

22. Mesa-Arango AC, Forastiero A, Bernal-Martínez L, Cuenca-Estrella M, Mellado E, Zaragoza 0. The non-mammalian host Galleria mellonella can be used to study the virulence of the fungal pathogen Candida tropicalis and the efficacy of antifungal drugs during infection by this pathogenic yeast. Med Mycol 2013;51:461-472.

23. Yuen GJ, Ausubel FM. Enterococcus infection biology: lessons from invertebrate host models. J Microbiol 2014;52:200-210.

24. Michaux C, Sanguinetti M, Reffuveille F, Auffray $Y$, Posteraro B, Gilmore $M S$, et al.. SlyA is a transcriptional regulator involved in the virulence of Enterococcus faecalis. Infect Immun 2011;79:2638-2645.

25. Yasmin A, Kenny JG, Shankar J, Darby AC, Hall N, Edwards C, et al.. Comparative genomics and transduction potential of Enterococcus faecalis temperate bacteriophages. J Bacteriol 2010;192:1122-1130.

Received August 18, 2014 Accepted December 31, 2014 